\title{
Mind the gender gap: the impact of university education on the entrepreneurial entry of female and male STEM graduates
}

\author{
Evila Piva · Paola Rovelli
}

Accepted: 10 June 2021 / Published online: 19 June 2021

(C) The Author(s) 2021

\begin{abstract}
Women are consistently underrepresented among graduate entrepreneurs. This is especially true among the entrepreneurs who graduate in STEM fields. Here, we aim at identifying factors that reduce/ enlarge the gender imbalance in entrepreneurship among STEM graduates. In particular, we explore the underinvestigated association between university education in STEM fields and entrepreneurial entry of recent female and male graduates considering graduates' whole university curriculum. Our analyses on the graduates who obtained a Master of Science degree in the 2005-2009 period from Politecnico di Milano reveal that training in economics and management reduces the gender imbalance in entrepreneurial entry among STEM recent graduates. The gap is instead larger among the graduates who attended courses that aggregate students from different STEM fields or did an internship.
\end{abstract}

E. Piva

Department of Management, Economics and Industrial

Engineering, Politecnico di Milano, via Lambruschini 4/b, 20156 Milano, Italy

e-mail: evila.piva@polimi.it

P. Rovelli $(\bowtie)$

Faculty of Economics and Management, Centre for Family Business Management, Free University of Bozen-

Bolzano, Universitätsplatz 1 - Piazza Università 1,

39100 Bozen-Bolzano, Italy

e-mail: paola.rovelli@unibz.it
Plain English Summary University education affects the gender gap in entrepreneurship among STEM graduates! Attending courses aggregating students from multiple STEM programs and doing internships enhance this gap, while training in economics and management reduces it. Women are severely underrepresented among STEM graduate entrepreneurs. Our study investigates the relationship between university education in STEM fields and entrepreneurial entry of recent female and male graduates. Using data on 13,840 graduates who obtained a Master of Science degree in the 2005-2009 period from Politecnico di Milano, we find that attending courses in economics and management reduces the gender imbalance in entrepreneurial entry among STEM recent graduates. The gap is instead larger among the graduates who attended courses aggregating students from different STEM fields or did an internship. Our study offers important implications for university managers, as it helps them design university curricula in STEM fields that may be more conducive to female entrepreneurial entry.

Keywords Female entrepreneurship - STEM · Entrepreneurial entry $\cdot$ University curriculum

JEL classifications $\quad \mathrm{L} 26 \cdot \mathrm{M} 13$ 


\section{Introduction}

Despite the increase in women's engagement in entrepreneurial activity over the years, there are still many more male than female entrepreneurs in most countries (Kelley et al., 2017). This gender gap in entrepreneurship is documented also among graduates, i.e., the individuals who have more potential to be successful entrepreneurs (Van der Sluis et al., 2008), and is particularly evident among graduates in the fields of science, technology, engineering, and mathematics (STEM fields) (e.g., Wadhwa \& Chideya, 2014). The gender gap in entrepreneurship among STEM graduates is particularly worrisome. As STEM graduates are major drivers of technological innovation (Breznitz \& Zhang, 2020), entrepreneurs with STEM backgrounds are expected to generate innovative ventures that can significantly contribute to the wealth and economic dynamism of nations. Therefore, the gender gap in entrepreneurship among STEM graduates may have important drawbacks for the economic system, which is deprived of the added value that female entrepreneurs with STEM backgrounds can bring. Hence, it is relevant to understand how this gap is generated and how it could be reduced.

One reason why there are few women among the entrepreneurs with STEM backgrounds is the low share of female graduates in STEM degree programs (Dilli \& Westerhuis, 2018; Shapiro \& Sax, 2011). In addition to the low numbers of women earning STEM degrees, it seems that female STEM graduates are less likely than their male counterparts to choose the entrepreneurial profession; i.e., there is a gender imbalance in STEM graduates' actual involvement in new venture creation (hereinafter, entrepreneurial entry). Few studies have investigated why female STEM graduates are less likely to opt for a career as entrepreneurs (Kuschel et al., 2020), and there is still no consensus on how to reduce this gender imbalance. Our study contributes to this debate in the female entrepreneurship literature by investigating the link between differences in entrepreneurial entry by women and men with a STEM background and their university education. University education is a key driver of both entrepreneurial entry and subsequent venture performance (Van der Sluis et al., 2008). Many studies have examined the influence of the human and social capital developed through curricular and extracurricular activities on the formation of entrepreneurial intentions and, less frequently, on the actual involvement of individuals in new venture creation (Colombo \& Piva, 2020), but they rarely distinguish between women and men. Armuña et al. (2020) explore the impact of an extracurricular entrepreneurship education program on the formation of entrepreneurial intentions among STEM students and graduates and find that this effect does not differ between women and men. However, entrepreneurship education activities represent a limited portion of the educational experiences completed by women and men with a STEM background. It is thus worthwhile considering the whole university curriculum. In this study, we do so by focusing on recent graduates because if we examined the probability of STEM graduates creating a new venture at some later stages of their professional careers, too many confounding factors might interfere with the observed relation. Investigating the link between the entrepreneurial entry of women and men and the university education they earned in STEM fields has obvious practical relevance. It may help both university managers to design university curricula that are more conducive to female entrepreneurial entry, and female students interested in an entrepreneurial career to choose a more suitable university curriculum.

Extant studies on female entrepreneurship indicate that key obstacles to female entrepreneurial entry are women's lack of self-confidence, their smaller networks, and discrimination from resource providers (e.g., Brana, 2013; Carter et al., 2003; Moore $\&$ Buttner, 1997). As we show in the following, the severity of these obstacles is influenced by university education. Thus, we investigate the role of three characteristics of STEM graduates' university curricula that may contribute to alleviate the abovementioned obstacles, namely training in economics and management fields, attendance of courses aggregating students from different STEM degree programs (hereafter, multi-program courses), and participation in internships. We argue that these three characteristics may more strongly affect the likelihood of recent female STEM graduates becoming entrepreneurs compared to recent male STEM graduates by increasing the returns that female graduates expect to reap 
in the entrepreneurial profession. To test the links between the above characteristics of STEM university curricula and entrepreneurial entry of recent female and male graduates, we use data on the population of graduates who obtained a Master of Science degree at the Politecnico di Milano. The Politecnico di Milano is the largest Italian technical university and ranks as one of the best universities worldwide in the STEM fields of Engineering, Architecture, and Industrial Design.

Our econometric estimates confirm the existence of a gender imbalance in entrepreneurial entry among recent STEM graduates: women are less likely to become entrepreneurs immediately after graduation. This imbalance is overcome among the graduates who attended one or more courses in economics and management during university studies, maybe because the competences developed through these courses increase women's self-confidence and reduce gender discrimination in resource allocation. Conversely, the gender imbalance in entrepreneurial entry increases among the graduates who attended multiprogram courses because recent female STEM graduates are probably less able than males to leverage the network relations with colleagues established during university studies. The imbalance increases also among the graduates who did internships, because through internships male and especially female graduates probably find job opportunities alternative to founding their own ventures. These results contribute to extend knowledge on female entrepreneurship by providing a deeper understanding of how university education in STEM fields differently influences the entrepreneurial entry of recent female and male graduates, and thus the gender gap in entrepreneurship.

This paper is structured as follows. In Section 2, we first review extant studies on female entrepreneurship to introduce the main difficulties that prevent women's entrepreneurial entry. The recognition of these obstacles later guides the selection of the characteristics of university education to be investigated and the hypothesis development. In Section 3, we present the data we use to test our hypotheses. In Section 4, we introduce the methodology we employ to analyze the data and derive the results we present in Section 5. Finally, in Section 6, we discuss the results and conclude by discussing contributions to theory, managerial implications, and future research avenues.

\section{Theoretical background and hypotheses}

2.1 Explanations for the gender imbalance in entrepreneurial entry

As we mentioned above, although the number of female entrepreneurs is increasing in many countries, a lower proportion of women than men engage in entrepreneurship in all developed economies (e.g., Georgellis \& Wall, 2005; Meyer et al., 2017; Minniti \& Nardone, 2007) and entrepreneurship is still perceived as a masculine profession (Meyer et al., 2017). Many scholars try to explain the relatively low entrepreneurial entry rates of women compared to men. Several studies show that the lower likelihood of women becoming entrepreneurs is not explained by a different ability in recognizing opportunities (see e.g., McDonnell \& Morley, 2015); indeed, irrespective of the opportunities recognized, women and men have different probabilities of choosing an entrepreneurial career. The literature points out two groups of reasons for the lower probability of women engaging in entrepreneurship. The first group includes a series of individual characteristics more frequently associated with the female gender. For instance, women are typically more risk adverse than men, and risk aversion limits their propensity towards entrepreneurial entry (e.g., Gimenez-Jimenez et al., 2020; Jianakoplos \& Bernasek, 1998). Similarly, differences in genetic aspects, personality traits (e.g., extraversion), selfperception (e.g., self-confidence), education, and personal relationships might reduce women's tendency to become entrepreneurs compared to men's (e.g., Brush, 1992; Verheul et al., 2005; Zhang et al., 2009). The second group of reasons includes aspects such as the cultural and institutional context (e.g., Estrin \& Mickiewicz, 2011) and the negative perception and evaluations from which women suffer (e.g., Baron et al., 2001; Fay \& Williams, 1993) due to diffused gender stereotypes (e.g., Marlow $\&$ Patton, 2005). In this work, we focus on three of the antecedents of women's lower propensity to choose an entrepreneurial career that are debated in the literature on female entrepreneurship, namely women's lack of self-confidence, their lower human capital and smaller networks, and the gender discrimination in resource allocation. We consider 
these three aspects because, as we explain in the following section, they might be affected by the university education earned by female graduates.

"A lack of confidence is perhaps the greatest barrier to women's progression into micro and small business ownership" (Fielden et al., 2003, p. 162). Self-confidence is indeed an important driver of entrepreneurial entry (e.g., Arenius \& Minniti, 2005; Koellinger et al., 2007). Women may be held back in founding their own ventures because they tend to be less self-confident (Bengtsson et al., 2005; Brana, 2013; Kirkwood, 2009; Langowitz \& Minniti, 2007), in particular with reference to their capability to run a business (Verheul \& Thurik, 2001). Because of cultural beliefs about gender roles, women perceive themselves as less competent and able in general (Kirkwood, 2009), and especially in tasks normally seen as masculine, such as entrepreneurship (Nowiński et al., 2019; Thébaud, 2010). Moreover, women tend to view themselves, their abilities and entrepreneurial ideas, and the entrepreneurial environment in a less optimistic way than their male counterparts do (Langowitz \& Minniti, 2007). Women's perception of lower skills and abilities and lack of optimism further limit self-confidence (Wilson et al., 2007) and convince them they will reap low returns in the entrepreneurial profession. Moreover, individuals with limited self-confidence are more risk averse; they tend to perceive more barriers and obstacles, and thus see situations or decisions as more risky (Brindley, 2005). As a result, women are less likely to start new businesses compared to men.

Besides women's lack of self-confidence, the gender gap in entrepreneurship has traditionally been thought to be fueled by differences in human and social capital (Greene, 2000). Human capital, i.e., the skills developed through education, work experience, and any other types of experience (Becker, 1964), helps entrepreneurs in attracting funds and other resources they need (e.g., Robb \& Robinson, 2014) and in successfully running their ventures (Carter et al., 1997; Coleman, 2000; Cooper et al., 1994; Pena, 2002). As such, human capital is fundamental for entrepreneurial entry (Kim et al., 2006). Women typically face barriers in acquiring adequate human capital (Carter et al., 1997). Although nowadays in advanced countries women and men have similar levels of education, they differ in their educational backgrounds, with women more likely to have a background in liberal arts and literature rather than technical disciplines (Brush, 1992; Walters \& McNeely, 2010). The skills acquired through education in the former fields are probably less applicable in the entrepreneurial profession and, thus, perceived as conducive to lower expected returns from the entrepreneurial career. Moreover, women are less likely than men to have previous experiences in owning businesses or working in private firms (Cromie \& Birley, 1990) and more frequently have career interruptions (e.g., for maternity leave periods) (Kaplan, 1988), which can lead to losses in skills and knowledge, thus damaging their human capital.

Differences between women and men also exist in their social capital, i.e., the resources that individuals have access to through their social network relations (Lin, 2001; Taylor et al., 2004). The network of an entrepreneur may include friends, family members, colleagues, other entrepreneurs, customers, employees, or investors who can provide the entrepreneur with access to resources and competences that may be valuable to found her/his venture and make it grow (e.g., Coviello \& Cox, 2006). Having access to networks of individuals able to provide useful resources and competences is thus essential for entrepreneurial entry (e.g., Greve \& Salaff, 2003). Women face peculiar challenges when accessing networks (Moore \& Buttner, 1997); they still struggle in accessing male-dominated professional networks (e.g., Hampton et al., 2009), being less welcome and marked out by men as strangers (Marlow \& McAdam, 2012). This induces women to feel excluded from conversations and information exchanges (Marlow \& McAdam, 2012), and to rely on networks managed through informal relations ${ }^{1}$ (e.g., McClelland et al., 2005). These networks are smaller and denser (Farr-Wharton \& Brunetto, 2007) and entail lower quality information and fewer and redundant resources (Hampton et al., 2011). This is in line with the evidence that female business owners gain access to networks that are not as extensive as those of their male counterparts (Aldrich et al., 1989; Brush, 1992). Furthermore, these networks are also

\footnotetext{
${ }^{1}$ Formal relations are those regulated by contracts or agreements, or professional relations (e.g., Kapucu \& Hu, 2016). All the remaining relations (e.g., relations with friends or family members) are informal.
} 
mainly formed by women (Aldrich et al., 1989), as both women and men tend to establish relations with same gender individuals. Differences between women and men have been found also in the number and type of networks they access. While men tend to exploit only one large network, women tend to rely on two parallel types of networks: one to obtain emotional support and another to obtain advice and information (Ibarra, 1997). Still, women spend less time in developing and maintaining relations with the members of these networks compared to men (Cromie \& Birley, 1990). Having smaller, more fragmented and less well-maintained network contacts puts prospective female entrepreneurs at a disadvantage in accessing the resources necessary for business creation and growth and negatively affects their expected returns from entrepreneurial entry.

Women face difficulties in launching their ventures also because they are discriminated by resource providers, especially capital providers (Carter et al., 2003). Among other factors, an entrepreneur's success depends on her/his ability to gather financial support for her/his venture, which plays a crucial role in venture survival and growth (Amit et al., 1990; Berger \& Udell, 1998). Access to financing is a great challenge for female entrepreneurs (Alsos et al., 2006; Azam Roomi et al., 2009; Harrison \& Mason, 2007) because investors are typically influenced by gender stereotypes (Eagly \& Karau, 2002), according to which women are less competent (e.g., De Pater et al., 2010; Northouse, 2003; Oakley, 2000; Yang \& Aldrich, 2014) and trustworthy (e.g., Brescoll, 2016; Hacker, 1951) than men. These stereotypes lead investors to differently value female entrepreneurs (Carter et al., 2007; Eddleston et al., 2016; Kanze et al., 2018), associating poorer evaluations to their business ideas (Malmström et al., 2017, 2018; Tinkler et al., 2015). Lower expectations are indeed developed towards women's abilities and business plan viability compared to those of men (Thébaud, 2015). This, in turn, results in investors conveying fewer resources to female entrepreneurs than to male entrepreneurs (Brana, 2013; Verheul \& Thurik, 2001). Female entrepreneurs have indeed lower access to venture capital (e.g., Malmström et al., 2017; Scott \& Shu, 2017; Tinkler et al., 2015) and business angel financing (e.g., Edelman et al., 2018; Poczter \& Shapsis, 2018). Ventures led by female entrepreneurs are also less likely to get access to bank credit (e.g.,
Ongena \& Popov, 2016; Thébaud \& Sharkey, 2016) and, when succeeding, are charged higher interest rates (Wu \& Chua, 2012). This limited access to debt capital is attributable not only to stereotypes, but also to the typically smaller startup size of female-led ventures, which makes them perceived as riskier and, thus, less attractive for debt capital providers (Coleman, 2000; Verheul \& Thurik, 2001).

The obstacles to female entrepreneurial entry described so far are more severe when considering entrepreneurship in STEM fields, where female entrepreneurs are even more underrepresented (Wadhwa \& Chideya, 2014).

2.2 The impact of university education on the gender imbalance in entrepreneurial entry

As described in the previous section, the lower likelihood of women entering entrepreneurship is partly explained by gender differences in human capital. However, several other factors make the returns women expect to obtain in the entrepreneurial profession lower than those of men, thus making women less willing to become entrepreneurs. Therefore, even when considering individuals with similar human capital, such as groups of recent STEM graduates, we expect to find lower shares of entrepreneurs among women. Our baseline hypothesis thus follows.

\section{H1: Recent female STEM graduates are less likely to become entrepreneurs after graduation than recent male STEM graduates.}

We contend that several characteristics of university education in STEM fields may play a role in helping recent female graduates overcome this imbalance in entrepreneurial entry. As a start, we consider training in economics and management. The economics and management courses offered in STEM degree programs provide students with basic knowledge that may help them avoid the most damaging mistakes in organizing and managing the activities of their nascent startups (Colombo \& Piva, 2020). Acquiring this knowledge may lead recent female STEM graduates to perceive they possess adequate human capital to pursue an entrepreneurial career, thus fostering their self-confidence (Wilson et al., 2007). Moreover, training in economics and management may allow recent female STEM graduates to alleviate the negative 
effects of gender discrimination in resource allocation. As we already mentioned, one of the reasons why providers of capital and other resources are less willing to give female entrepreneurs access to their resources is that women are stereotypically seen as less competent in business than men (Oakley, 2000). The training received in economics and management fields may help female STEM graduates build a common language and reciprocal understanding (e.g., Clark, 1996) with resource providers. This common language and understanding may in turn help female STEM graduates cope with gender stereotypes, thus facilitating interactions and communication (e.g., Chwe, 2001) with resource providers and access to external resources.

As training in economics and management fields results in increased self-confidence and lower gender discrimination, it should have more positive effects on the returns recent female STEM graduates expect to reap in the entrepreneurial profession compared to those of their male counterparts. Therefore, the relative likelihood of recent female STEM graduates becoming entrepreneurs will increase. The second hypothesis follows.

H2. Training in economics and management reduces the gender imbalance in entrepreneurial entry among recent STEM graduates.

Besides providing graduates with adequate human capital to become entrepreneurs, university education in STEM fields may provide access to a network of knowledgeable individuals in the university environment. Attending university courses provides a favorable forum to locate competent co-founders or to discuss business ideas with fellow students or professors (Walter et al., 2013). After graduation, the network contacts established while attending university courses may be leveraged by prospective graduate entrepreneurs to gain access to the knowledge and resources they may need to establish new ventures. Attending courses that aggregate students from different STEM degree programs helps students to include more diverse contacts in their networks, which may provide access to knowledge from different technical fields. Including multi-program courses in STEM university curricula may be particularly beneficial for women. These courses may indeed help women broaden their typically smaller networks (e.g.,
Farr-Wharton \& Brunetto, 2007), and thus have more positive effects on the returns female graduates expect to reap from the entrepreneurial profession than on those of male graduates, and be more conducive to new venture creation by female graduates. Hence, we formulate the following hypothesis.

H3. Attending multi-program courses reduces the gender imbalance in entrepreneurial entry among recent STEM graduates.

Also doing an internship may have positive effects on the social networks of STEM graduates. Through internships, interns can establish professional relationships that cannot be built in the university environment (Bittmann \& Zorn, 2020) and may be leveraged when the interns eventually engage in entrepreneurial activities. Probably, these relationships are particularly beneficial for the graduates who encounter greater difficulties in establishing large networks, such as women. Hence, doing an internship may have more positive effects on the returns from entrepreneurial entry expected by female STEM graduates. However, it is worth recognizing that doing internships also facilitates STEM graduates' job search; interns are often hired by the same companies where the internships are completed or by related employers (Bittmann \& Zorn, 2020). Hence, doing an internship increases also the opportunity costs of entrepreneurial entry, given by graduates' lost wages as salaried employees. This effect should be particularly relevant for women, who tend to suffer from job segregation in STEM fields (Jasko et al., 2020) and thus may benefit more from internships. Therefore, doing an internship probably increases the opportunity costs of female STEM graduates more than those of their male counterparts.

To sum up, we expect that doing an internship has contrasting effects on the gender imbalance in entrepreneurial entry among recent STEM graduates. Completing an internship reduces this imbalance by realigning female and male expectations on the returns from the entrepreneurial profession, while simultaneously accruing the imbalance by disproportionately increasing the opportunity costs associated to the entrepreneurial entry of female graduates. As we cannot predict the result of these overlapping forces, we formulate competing hypotheses about the effect of internships on the difference between recent 
female and male STEM graduates in the likelihood of becoming entrepreneurs immediately after graduation and leave to the empirics to determine which effect prevails.

H4a. Doing an internship reduces the gender imbalance in entrepreneurial entry among recent STEM graduates.

H4b. Doing an internship increases the gender imbalance in entrepreneurial entry among recent STEM graduates.

\section{Data}

\subsection{The database}

To explore the effects of university education on the entrepreneurial entry of recent male and female STEM graduates, we compiled a unique cross-sectional dataset including information on the population of individuals who obtained a Master of Science (hereafter, MSc) degree at the Politecnico di Milano (hereafter, POLIMI) between July $2005^{2}$ and December 2009. As POLIMI is a technical university, all its graduates receive university education in STEM fields.

Our dataset combines two types of data. First, it stores demographic data and information concerning the university curriculum of 13,840 graduates. These graduates constitute the population of individuals who obtained a Master of Science in any degree program offered at POLIMI in the period under scrutiny. ${ }^{3}$ For each graduate in the population, the dataset

\footnotetext{
2 The students who graduated in Italy in July 2005 were the first who obtained a Master of Science degree in the new university system. Indeed, the Italian university system was reformed in the 1999/2000 academic year to comply with the Bologna process directives. The old system consisted in a single course, from four to six years, depending on the degree program, leading to a Master of Science degree called Laurea. The new university system includes two degree levels: a threeyear Bachelor degree (called Laurea di Primo Livello), and a two-year course of specialization, leading to the Master of Science degree (called Laurea Magistrale).

3 This population does not include the graduates who had peculiar university curricula, namely those who obtained two (or more) MSc degrees at POLIMI or one MSc degree after obtaining either a Laurea degree in the old university system or two (or more) Bachelor degrees.
}

includes the following information: social security number, gender, date and country of birth, name of the MSc program attended (and, in case of graduates who obtained also a Bachelor degree at POLIMI, name of the Bachelor program), year of enrolment in the degree program, list of courses attended at POLIMI including curricular internships, final degree grade, and date of graduation. All these data were provided by the POLIMI administrative office.

Second, the dataset stores information on the limited liability companies founded in Italy by the 13,840 POLIMI graduates (i.e., the companies where the graduates were listed as shareholders in the year of incorporation) between graduates' birth years and December 2014. Specifically, it includes the following information: the VAT codes and NACE codes of activity of all the Italian companies where the 13,840 graduates have ever been listed as shareholders, the year of incorporation of each company and the year(s) when each graduate acquired shares in the company (companies) of which s/he has ever been a shareholder. These data were gathered by searching for the fiscal code of the 13,840 graduates in the Italian Business Register ${ }^{4}$ and downloading the data of interest.

Out of the 13,840 graduates included in the population, 73 graduates $(0.5 \%)$ founded one (or more) companies during university studies. These 73 graduates are not considered in the following analyses because, as we are interested in investigating the impact of university education on the entrepreneurial entry of female and male graduates, it is worth focusing on firm creation by individuals who have already completed the educational program. In the following analyses, we also exclude six graduates who became shareholders of companies after graduation, but for whom the available information does not allow us to understand whether they were listed as shareholders in the year of incorporation. Among the remaining 13,761 graduates, 468 (i.e., 3.4\%) founded at least one limited liability company between graduation year and December 2014, while 13,284 did not enter entrepreneurship in the period under scrutiny.

\footnotetext{
4 The Italian Business Register is the public register created by the Italian Chambers of Commerce to gather basic information (i.e., incorporation, amendments, cessation of trading) for all companies with any legal status and operating in any sector of economic activity, with headquarters or local branches within the country.
} 
Table 1 Individual characteristics of female and male POLIMI graduates distinguishing between those who entered entrepreneurship after graduation (i.e., graduate entrepreneurs) and the remaining graduates (i.e., graduate non-entrepreneurs)

\begin{tabular}{|c|c|c|c|c|c|c|c|c|}
\hline & \multicolumn{4}{|c|}{$\begin{array}{l}\text { POLIMI graduate entrepreneurs } \\
(\mathrm{N}=468)\end{array}$} & \multicolumn{4}{|c|}{$\begin{array}{l}\text { POLIMI graduate non-entrepre- } \\
\text { neurs } \\
(\mathrm{N}=13,293)\end{array}$} \\
\hline & \multicolumn{2}{|c|}{$\begin{array}{l}\text { Female gradu- } \\
\text { ates } \\
(\mathrm{N}=89)\end{array}$} & \multicolumn{2}{|c|}{$\begin{array}{l}\text { Male graduates } \\
(\mathrm{N}=379)\end{array}$} & \multicolumn{2}{|c|}{$\begin{array}{l}\text { Female graduates } \\
(\mathrm{N}=4,617)\end{array}$} & \multicolumn{2}{|c|}{$\begin{array}{l}\text { Male gradu- } \\
\text { ates } \\
(\mathrm{N}=8,676)\end{array}$} \\
\hline & No & $\%$ & No & $\%$ & No & $\%$ & No & $\%$ \\
\hline \multicolumn{9}{|l|}{ Country of birth } \\
\hline Italy & 87 & 97.8 & 369 & 97.4 & 4,255 & 92.2 & 8,136 & 93.8 \\
\hline Other countries & 2 & 2.2 & 10 & 2.6 & 362 & 7.8 & 540 & 6.2 \\
\hline \multicolumn{9}{|l|}{ University fee level } \\
\hline Highest fee level & 17 & 19.1 & 65 & 17.2 & 543 & 11.8 & 969 & 11.2 \\
\hline Any other fee level & 72 & 80.9 & 314 & 82.8 & 4,074 & 88.2 & 7,707 & 88.8 \\
\hline \multicolumn{9}{|c|}{$\begin{array}{l}\text { Exposure to entrepreneurial experiences before enrolling in the Master of Science degree pro- } \\
\text { gram at POLIMI }\end{array}$} \\
\hline $\begin{array}{l}\text { Shareholders in one } \\
\text { or more companies } \\
\text { before enrolment }\end{array}$ & 2 & 2.2 & 21 & 5.5 & 36 & 0.8 & 86 & 1.0 \\
\hline $\begin{array}{l}\text { Shareholders of no } \\
\text { companies before } \\
\text { enrolment }\end{array}$ & 87 & 97.8 & 358 & 94.5 & 4,581 & 99.2 & 8,590 & 99.0 \\
\hline
\end{tabular}

3.2 Descriptive statistics on female and male POLIMI graduates

In this section, we illustrate descriptive statistics aimed at highlighting differences between female and male POLIMI graduates, distinguishing between the graduates who founded at least one venture after graduation (hereafter labeled "graduate entrepreneurs") and the remaining ones (hereafter labeled "graduate non-entrepreneurs"). As usual in STEM degree programs, women are underrepresented among POLIMI graduates: only $34.2 \%$ of the graduates in the population are women (4,706 women vs. 9,055 men). The share of women among POLIMI graduate entrepreneurs is even lower $(19.0 \%$; 89 women vs. 379 men). The difference between these two shares is significant, thus suggesting that a difference in the likelihood of entrepreneurial entry exists between female and male POLIMI graduates. In line with $\mathrm{H} 1$, female POLIMI graduates are on average less likely to become entrepreneurs after graduation than male POLIMI graduates.

Table 1 compares four groups of POLIMI graduates (female graduate entrepreneurs, male graduate entrepreneurs, female graduate non-entrepreneurs, and male graduate non-entrepreneurs) along the individual characteristics for which data are available in our dataset, namely geographic origin, financial endowment, and prior exposure to entrepreneurial experiences.

As to the geographic origins of POLIMI graduates, non-Italian-born graduates in the population are few (much less than 10\%). The share of non-Italian-born female graduate non-entrepreneurs $(7.8 \%)$ is significantly higher than the share of non-Italian-born male graduate non-entrepreneurs $\left(6.2 \% ; \chi^{2}(1)=12.45^{* * *}\right)$. Conversely, the share of non-Italian-born graduates is similar when comparing female and male graduate entrepreneurs $\left(2.2\right.$ vs. $\left.2.6 ; \chi^{2}(1)=0.04\right)$. It is worth noting that among both female and male POLIMI graduates, non-Italian-born graduates are less likely to enter entrepreneurship after graduation than Italian-born ones $\left(\chi^{2}(1)=3.83^{*}\right.$ and $\chi^{2}(1)=8.18^{* * *}$, respectively).

As it is a stylized fact that financial barriers often inhibit entrepreneurial entry, it is interesting to explore if any differences exist between female and male POLIMI graduates as to financial endowment. To this purpose, we use data on university fee payments of POLIMI graduates in the academic year of graduation. POLIMI has 10 fee levels, ranging from one (corresponding to full exemption from paying 
university fees) to 10 (corresponding to the highest university fees). The fee level is determined for each student based on the value of the Indicator of Equivalent Economic Situation (ISEE) provided by the Italian National Social Security Institute. This indicator estimates the economic situation of the student's family by considering the family's total income and properties (i.e., houses, shares, assets, dividends), and the composition of the family. In line with the findings of prior studies, our evidence indicates that personal financial resources are positively associated to the propensity of starting a new venture for both female and male graduates: the share of graduates who were assigned the highest fee level is indeed significantly higher among graduate entrepreneurs than among graduate non-entrepreneurs, being the graduates women $\left(19.1 \%\right.$ vs. $\left.11.8 \% ; \chi^{2}(1)=4.49 * *\right)$ or men $\left(17.2 \%\right.$ vs. $\left.11.2 \% ; \chi^{2}(1)=12.84 * * *\right)$. No differences exist between women and men as to the share of graduates who were assigned the highest fee level $\left(\chi^{2}(1)=0.19\right.$ in the group of graduate entrepreneurs; $\chi^{2}(1)=1.05$ in the group of graduate non-entrepreneurs).

Our dataset also allows us to identify the graduates who owned shares in one or more companies when they enrolled in the MSc degree program at POLIMI and, thus, had been already exposed to entrepreneurial experience. Such experience might facilitate entrepreneurial entry after graduation because it may provide graduates with competences, contacts, and resources that might be used in the new ventures. Interestingly, the share of graduates who were shareholders of companies when they enrolled in POLIMI MSc degree programs is higher for graduate entrepreneurs than for graduate non-entrepreneurs, being the graduates women $(19.1 \%$ vs. $11.8 \%)$ or men $(17.2 \%$ vs. $11.2 \%)$. However, the difference between graduate entrepreneurs and graduate non-entrepreneurs is significant only for men $\left(\chi^{2}(1)=2.35 ; \chi^{2}(1)=64.22 * * *\right)$. No differences exist between women and men as to the share of graduates who were shareholders of one or more companies at the time of enrolment $\left(\chi^{2}(1)=1.67\right.$ in the group of graduate entrepreneurs; $\chi^{2}(1)=1.48$ in the group of graduate non-entrepreneurs).

\section{Methodology of the econometric analysis}

To analyze the different effects of university education on the entrepreneurial entry of recent female and male POLIMI graduates, we estimate Probit and Logit models because our outcome variable (DEntrepreneurialEntry) is dichotomous. DEntrepreneurialEntry equals one for the graduates who founded a new venture in the graduation year or in the following year, ${ }^{5}$ and zero for the remaining POLIMI graduates. We estimate robust standard errors by clustering observations by degree program. As the results of the Probit and Logit models are very similar, in Section 5 we report only the former. The results of the Logit models are available from the authors upon request.

The key explanatory variable is DFemale_Graduate, a dummy equaling one for women and zero for men. The explanatory variables capturing the characteristics of university education under scrutiny are three: DEconomics, AvgShareOtherDegrees, and DInternship. DEconomics is a dummy equal to one for POLIMI graduates who attended at least one course in the fields of Economics, Management, and Management Engineering during the MSc. AvgShareOtherDegrees captures attendance of multi-program courses. To build this variable, we computed a ratio for each course attended by each POLIMI graduate. The denominator was the total number of POLIMI graduates who passed the course final exam in the year $t$ when the focal graduate passed it. The numerator included only the graduates who passed the course final exam in $t$ and were enrolled in POLIMI MSc degree programs different from the focal graduate's program. AvgShareOtherDegrees was then computed as the mean value of the ratio across all the courses attended by the focal graduate. DInternship is a dummy equaling one for the graduates who did a curricular internship during the MSc. For 281 graduates, we do not have complete information about the

\footnotetext{
${ }^{5}$ We consider this short timespan after graduation because, as time after graduation passes, graduates accumulate work experience that is likely to affect entrepreneurial entry both separately and in combination with university education. As we have no data about the post-graduate work experience of POLIMI graduates, we are unable to disentangle the effects of university education and work experience. Hence, to reduce possible biases in the results, we chose to limit our analysis to the graduation year and the year after.
} 
characteristics of university education under scrutiny, hence, in the econometric estimates, we focus on the 13,480 graduates for whom we could compute all the explanatory variables.

The control variables include determinants of entrepreneurial entry derived from the literature. To control for the financial endowment of the focal graduate, we consider the dummy variable DHighest_Fees, which is equal to one for the graduates who were assigned to the highest fee level and zero otherwise. We control for prior exposure to entrepreneurial experience through the dummy variable DPrior_Shareholder, equaling one for the graduates who owned shares in one or more companies when they enrolled in the MSc degree program at POLIMI and zero for the remaining graduates. As the literature suggests that the age of an individual may affect her/his decision to start a new venture (see, e.g., Levesque \& Minniti, 2006), we control for age at graduation (Age_at_graduation), winsorized at 1 st and 99th percentiles to correct for outliers. Moreover, as the descriptive statistics discussed above reveal lower shares of graduate entrepreneurs among nonItalian-born graduates, we include DBorn_Abroad, which is a dummy equaling one for the graduates who were not born in Italy. We also control for Graduation_Grade, which is the grade the focal graduate obtained at the end of the MSc and ranges from 60 to $110,{ }^{6}$ and DLate_Graduate, which is a dummy variable equal to one for the graduates who took more than two academic years to obtain the MSc degree. These latter graduates may be less brilliant than the graduates who succeeded in obtaining the degree title in two academic years or they may have been working students. Finally, we consider two sets of dummy variables respectively capturing the year of graduation of the focal individual and the School to which his/her degree program pertained. ${ }^{7}$

\footnotetext{
${ }^{6}$ As a robustness check, we repeated the estimates presented in Section 5 after equalling to 113 the grade of the individuals who graduated cum laude. Results are similar to the ones shown in the text and are available from the authors upon request.

7 During the years under scrutiny, POLIMI degree programs were organized into 6 Schools: the School of Architecture and Society, the School of Civil Architecture, the School of Design, the School of Civil, Environmental and Land Management Engineering, the School of Architectural Engineering, and the School of Industrial and Information Engineering.
}

The descriptive statistics on the variables included in the econometric estimates (with the exception of the year and School dummies) and the correlation matrix are reported in Table 2.

\section{Results}

\subsection{Main econometric estimates}

Table 3 reports the results of the estimates using DEntrepreneurialEntry as dependent variable. Model 1 includes only the control variables. It is fair to acknowledge that, in line with studies on the antecedents of entrepreneurial entry that consider other populations of individuals (e.g., Kacperczyk, 2013; Özcan \& Reichstein, 2009), the explanatory power of the model is low (Pseudo R2 is equal to 0.054). This is a consequence of both the low percentage of POLIMI graduates who become entrepreneurs immediately after graduation and the high number of factors that may influence recent graduates' entrepreneurial entry decisions. Nonetheless, our estimates confirm that individual characteristics are important determinants of graduates' entrepreneurial entry (for a similar result, see Bergmann et al., 2016; Colombo \& Piva, 2020). The positive and highly significant coefficients of DHighest_Fees and DPrior_Shareholder respectively indicate that, in line with prior studies, recent university graduates are more likely to become entrepreneurs the wealthier their families of origin are (Dunn \& Holtz-Eakin, 2000) and when they have already been exposed to entrepreneurial experience through household or personal experience (Carroll \& Mosakowski, 1987; Roberts, 1991; Sørensen, 2007). The magnitude of the effects of these variables is considerable: the average probability of entrepreneurial entry triples for the wealthiest graduates (from $0.7 \%$ when DHighest_Fees $=0$ to $2 \%$ when DHighest_Fees =1) and is seven times greater for the graduates who have already been exposed to entrepreneurial experience (from $0.7 \%$ when DPrior_Shareholder $=0$ to 5\% when DPrior_Shareholder $=1$ ). Moreover, in line with the descriptive statistics discussed above, the negative coefficient of DBorn_Abroad indicates that non-Italian-born graduates are less likely to establish new ventures in Italy immediately after graduation. The average probability of entrepreneurial entry decreases by $94 \%$ for 


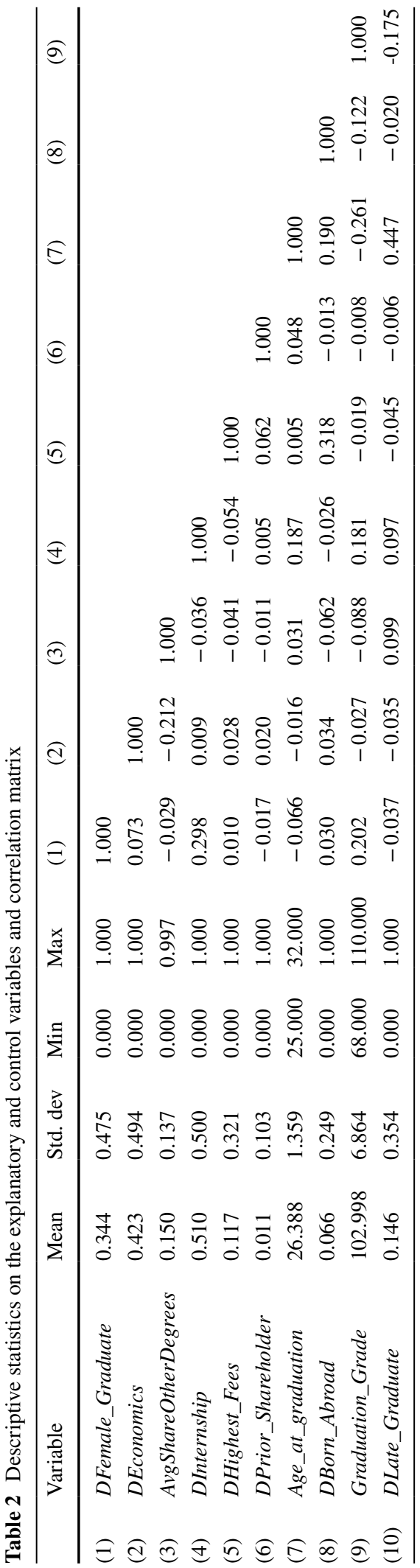

non-Italian-born graduates compared to Italian-born ones $(0.9 \%$ when DBorn_Abroad $=0$ vs. less than $0.1 \%$ when DBorn_Abroad=1).

Model 2 adds the key explanatory variable $\mathrm{DFe}$ male_Graduate and the variables capturing the characteristics of university education under scrutiny. Quite interestingly, the insertion of these variables substantially improves the (still low) explanatory power of the model; indeed, the McFadden's Adjusted R2 increases from 0.031 to 0.041 . As the negative coefficient of DFemale_Graduate indicates, in line with $\mathrm{H} 1$, female graduates are less likely than male graduates to pursue an entrepreneurial career immediately after graduation. The economic magnitude of the effect of gender is not negligible: the probability of entrepreneurial entry decreases by $47 \%$ (from 0.97 to $0.51 \%$ ) for female graduates compared to male graduates. Quite interestingly, the three variables related to university education have significant coefficients as well. In particular, while DEconomics and AvgShareOtherDegrees have positive coefficients, the coefficient of DInternship is negative. As we discussed above, the competences developed through training in economics and management and the social relations developed with students having different technical specializations facilitate entrepreneurial entry. The average probability of entrepreneurial entry indeed increases by $78 \%$ for graduates who attended at least one course in economics and management fields and by $44 \%$ when AvgShareOtherDegrees increases from 0.03 (i.e., the variable mean value minus one standard deviation) to 0.26 (i.e., the mean value plus one standard deviation). Conversely, the likelihood of becoming entrepreneurs immediately after graduation drops on average of $49 \%$ for graduates doing internships because it probably helps them in finding jobs, either in the companies where they completed the internships or in other organizations.

Models 3-6 include the interactions between $\mathrm{DFe}$ male_Graduate and the three variables capturing the characteristics of university education under scrutiny. Specifically, models 3, 4, and 5 respectively add $D F e$ male_Graduate $\times$ DEconomics, DFemale_Graduate $\times$ AvgShareOtherDegrees, and DFemale_Graduate $\times$ DInternship, while model 6 includes all the interactive terms simultaneously. The positive coefficient of DFemale_Graduate $\times$ DEconomics and the non-significant coefficient of DEconomics in model 


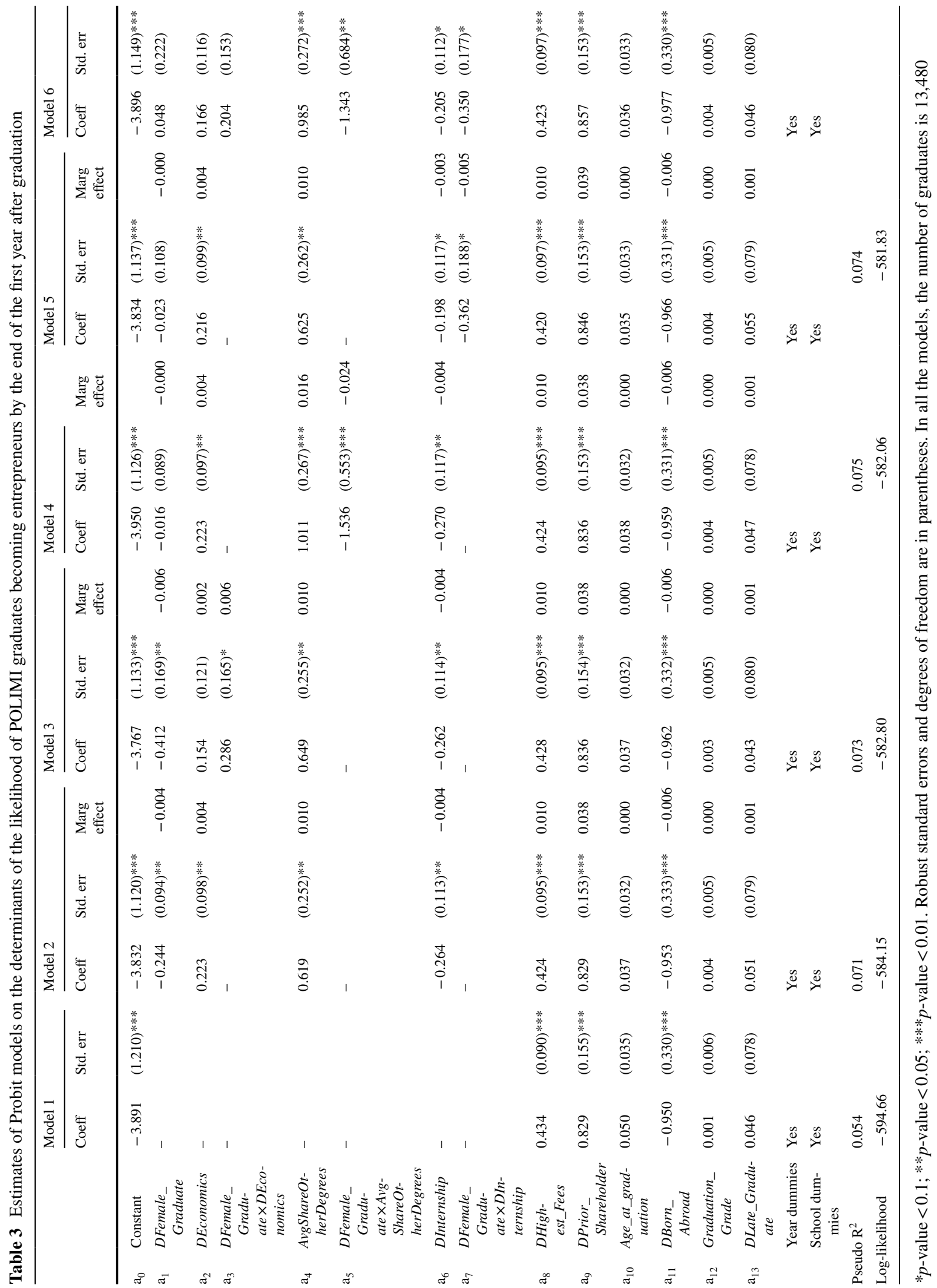


3 reveal that training in economics and management overcomes the gender imbalance in entrepreneurial entry. Among the graduates who did not attend any university courses in economics and management fields, the average probability of entrepreneurial entry after graduation is significantly lower for females $(0.26 \%)$ than for males $(0.81 \%)$. Conversely, among the graduates who attended at least one course in economics and management the difference between the probabilities of entrepreneurial entry for female and male graduates is much smaller $(0.87 \%$ for females vs. $1.19 \%$ for males) and non-significant. Training in economics and management increases the probability that female graduates become entrepreneurs in the graduation year or in the following one by $235 \%$ while the same probability increases only by $47 \%$ for male graduates. Hence, we conclude that $\mathrm{H} 2$ is supported.

Conversely, $\mathrm{H} 3$ is not supported by our estimates. Interestingly, the effect of attending multi-program courses is the exact opposite of our expectations: instead of reducing the difference between women and men in the likelihood of becoming entrepreneurs, it enhances it. Indeed, in model 4, AvgShareOtherDegrees has a significant positive coefficient whereas DFemale_Graduate $\times$ AvgShareOtherDegrees a significant negative one and the sum of the two coefficients is not significant. It follows that attending multi-program courses has no effects on the entrepreneurial entry of female graduates, while it has a positive and significant effect for male graduates. When AvgShareOtherDegrees increases from its mean value minus one standard deviation to the mean value plus one standard deviation, the average probability of entrepreneurial entry of male graduates increases by $79 \%$ (from 0.69 to $1.24 \%$ ), while the same probability for female graduates is slightly reduced (from 0.59 to $0.43 \%)$.

Finally, the negative coefficients of DInternship and DFemale_Graduate $\times$ DInternship in model 5 reveal that doing internships has a negative impact on the likelihood of entrepreneurial entry for both male and female graduates, but the effect is stronger for the latter. Doing internships reduces the average probability that females become entrepreneurs immediately after graduation by $77 \%$ (from 1.29 to $0.30 \%$ ), while the same probability decreases only by $39 \%$ (from 1.36 to $0.84 \%$ ) for males. Hence, we conclude that among the contrasting hypotheses $\mathrm{H} 4 \mathrm{a}$ and $\mathrm{H} 4 \mathrm{~b}$, our analysis provides support to $\mathrm{H} 4 \mathrm{~b}$.

\subsection{Additional analyses}

To check the robustness of the results presented in Section 5.1, we performed some tests (for the sake of conciseness, results are not reported here, but are available from the authors upon request). First, we used a different estimation method, namely matching. We considered three different treatments: completing courses in the economics and management fields during the MSc studies (i.e., DEconomics =1); completing courses on average attended by many students from different MSc studies (i.e., AvgShareOtherDegrees greater than its mean value); and doing at least one curricular internship during the MSc studies (i.e., DInternship =1). For each treatment, we matched each treated graduate with one untreated graduate in the same MSc degree program and ran the estimates of the models in Table 3 using the sample including only the treated and matched untreated graduates. The estimates show that the effects of the interaction between the gender dummy and the treatment variables are in line with those discussed above. This fact points to the robustness of our results.

Second, as the likelihood of entrepreneurial entry after MSc graduation may depend on university education at both Bachelor and MSc levels, we focused on the 12,315 graduates who obtained both the MSc degree and the Bachelor degree at POLIMI. As for these individuals, we have complete information about the courses attended and internships done during both Bachelor and MSc studies; we computed our explanatory variables DEconomics, AvgShareOtherDegrees, and DInternship considering also Bachelor education. ${ }^{8}$ The results of the estimates including these variables confirm the positive impact of training in economics and management on female entrepreneurial entry after graduation and the negative effect

\footnotetext{
${ }^{8}$ In these additional estimates, DEconomics equals one for the graduates who attended at least one course in the fields of Economics, Management, and Management Engineering during the Bachelor and/or the MSc; AvgShareOtherDegrees captures attendance of multi-program courses during Bachelor and MSc studies; and DInternship equals one for the graduates who did at least one curricular internship during the Bachelor and/or the MSc.
} 
of completing internships. Conversely, we do not find evidence of any differences between male and female graduates as to the effect of AvgShareOtherDegrees: although the value of the variable is higher when we consider both Bachelor and MSc courses, its effect becomes negligible for all the graduates. A possible reason is that leveraging the network contacts established in less recent years is difficult for both men and women. Hence, although during Bachelor studies POLIMI graduates have the opportunity to meet many students from different degree courses, they are unable to leverage the relationships eventually established with these individuals to launch new ventures after MSc graduation.

Third, we addressed the concern that selection issues may drive our results. In particular, one may think that POLIMI graduates who were willing to become entrepreneurs after graduation might have chosen to attend courses in economics and management to acquire competences and knowledge useful to run a new venture. Having entrepreneurial intentions before graduation represents an excluded variable that may correlate with both the explanatory variable DEconomics and the outcome variable capturing entrepreneurial entry, thus leading to a bias in the estimates. To rule out this concern, we used data collected through a survey we administered in October 2019 during lectures of a series of courses attended by POLIMI students who were at the beginning of the second year of different MSc degree programs. Using the data provided by the 329 survey respondents, we computed a measure of students' entrepreneurial intent, i.e., their intention to start a business at some time in the future. ${ }^{9}$ Then, we combined these data with information about the courses that the 329 students had selected during the academic year 2019-2020. This additional information

\footnotetext{
9 To measure students' intention to start a business in the future, we followed Liñán and Chen (2009) and asked respondents to indicate their level of agreement with the following five statements about entrepreneurial activity: (1) I am ready to do anything to be an entrepreneur; (2) my professional goal is to become an entrepreneur; (3) I will make every effort to start and run my own firm; (4) I am determined to create a firm in the future; (5) I have very seriously thought of starting a firm. Answers were provided using a Likert scale from 1 (total disagreement) to 7 (total agreement). The measure of entrepreneurial intent was computed as the average of the respondents' evaluations.
}

was used to compute a dummy equaling one for survey respondents who had selected courses in the economics and management fields. We used this dummy as the dependent variable in a Logit model where the independent variables included respondent gender, the measure of entrepreneurial intent, and the interactive term between these two variables. The estimates reveal that entrepreneurial intent does not influence the likelihood of either female or male students selecting courses in economics and management. This finding reassures us that no selection bias drives our results.

\section{Discussion and conclusions}

This paper investigates the relationship between university education in STEM fields and entrepreneurial entry of recent female and male graduates. The analysis of 13,480 recent STEM graduates who obtained a MSc degree at the Politecnico di Milano reveals that females are less likely than males to found new ventures soon after graduation. This result is in line with evidence provided by prior studies (Wadhwa \& Chideya, 2014). More interestingly, our study shows that, as we expected, the characteristics of the university education received by STEM graduates influence the magnitude of the gender imbalance in entrepreneurial entry. In particular, including courses in economics and management in the university curriculum reduces this imbalance. Training in economics and management indeed increases the probability of entrepreneurial entry of female STEM graduates only because it has positive effects on their expected returns from entrepreneurial entry. As courses in economics and management provide knowledge useful to run a new venture, attending such courses probably leads female STEM graduates to perceive they possess adequate human capital to pursue a successful entrepreneurial career. Moreover, the knowledge acquired in economics and management facilitates interactions with resource providers, thus helping female graduates cope with gender stereotypes and reducing gender discrimination in resource allocation. Conversely, attending multi-program courses and doing internships increase the difference between female and male graduates in the likelihood of becoming entrepreneurs. In particular, multi-program courses have no effects on the entrepreneurial 
entry of female STEM graduates, while they promote new firm creation by male graduates. Female STEM graduates seem less able than their male university mates to leverage the contacts they established with individuals with different competences while attending multi-program courses. This confirms that women face greater constraints in leveraging their networks (e.g., Hampton et al., 2009; Marlow \& McAdam, 2012; Moore \& Buttner, 1997). As to the effect of internships, both female and male STEM graduates who did internships are less likely to become entrepreneurs immediately after graduation than their counterparts who did not participate in internships, but this negative impact on entrepreneurial entry is stronger for women. As doing internships helps recent graduates in finding the first jobs, it increases the opportunity costs associated to entrepreneurial entry. Such increase is probably greater for women, who tend to be discriminated in the labor market (Jasko et al., 2020) and thus usually have low opportunity costs.

These results advance the literature on female entrepreneurship. Specifically, they contribute to extending our understanding of the factors that influence the gender gap in entrepreneurship. In particular, we focus on the role of university education that has not been adequately investigated so far. Several prior studies have explored the effect of the degree field and suggest that it helps explaining the gender differences in entrepreneurial entry. Women are less likely to become entrepreneurs because they more frequently earn degrees that provide knowledge hardly applicable in the entrepreneurial profession (Brush, 1992; Walters \& McNeely, 2010). Fairly recent studies focus on the impact of education in a specific field-entrepreneurship - that seems clearly conducive to new venture creation. These studies explore the differences between female and male students as to the effects of the competences developed through entrepreneurial education on their entrepreneurial intentions and other typical drivers of entrepreneurial entry (e.g., self-efficacy), and find contrasting results. While some works reveal more positive effects of entrepreneurial education on women (Wilson et al., 2007), others find negative (Westhead \& Solesvik, 2016) or negligible effects (Armuña et al., 2020). Our work adds to these two groups of studies by providing a threefold contribution. First, our results indicate that the impact university education can have on entrepreneurial entry reaches well beyond the effects of differences in the degree field and the influence of entrepreneurial education. Second, our fine-grained data on the university curricula of recent STEM graduates turning into entrepreneurs allow us to devote attention to the role of moderators of the relationship between earning a degree in STEM fields and the gender gap in entrepreneurship, and reveal that not only the degree field does matter, but also the composition of the university curriculum in the different degree fields. Third, while prior studies mainly use competence development arguments to explain the relationship between university education and gender differences in the probability of becoming entrepreneurs (Armuña et al., 2020; Wilson et al., 2007), our work highlights that also the network contacts developed during university studies matter. We indeed reveal that the severity of the gender imbalance in entrepreneurial entry is influenced by differences between men and women in leveraging these contacts.

As any other piece of work, this study is not devoid of limitations, which open for future research developments. First, here we focused on recent graduates. As we mentioned in the introduction, investigating the relationships under scrutiny would be more complex if we considered a longer time span after graduation, as many confounding factors might intervene. However, university education may affect the entrepreneurial entry of female and male graduates also in the long run; for instance, it may engender synergistic effects with peculiar types of work experience, or the effects of university education may be mediated by the work experience gained by graduates. To capture these effects, one should collect both the university curricula and data on the post-graduate work experiences of samples of STEM graduates. Second, we did not consider that individual characteristics may moderate the relationship between university education and the gender imbalance in entrepreneurial entry. For instance, we might expect that the obstacles to female entrepreneurial entry are more severe, and, thus, the importance of university education in helping women overcome these obstacles is greater for women educated in more masculine cultures or raised with no entrepreneurial role model. Exploring the combined effects of university education and individual characteristics, such as the culture of origin, on the gender gap in entrepreneurship 
would be extremely interesting. Third, we focused on one technical university that offers degrees only in engineering, architecture, and industrial design. Therefore, one may question the generalizability of our results to graduates in other STEM fields (i.e., science and mathematics), non-STEM graduates, and universities located in other geographical areas. We might expect that the effects of the university curricula examined here on the gender imbalance in entrepreneurial entry is smaller among graduates in fields where the share of graduate women is higher (e.g., some STEM fields such as biology and many non-STEM fields). Indeed, in these fields, female graduates likely encounter less severe problems in gaining access to the additional competences and resources they need to found a new venture. Similarly, we might expect that the characteristics of the geographical areas where universities are located may moderate the effects of the university curricula on the gender imbalance in entrepreneurial entry. For instance, these effects may be weaker the greater the local availability of resources useful to establish a new venture (e.g., skilled human resources, financial resources). Hence, it would be worthwhile repeating our analyses on graduates in different (STEM and non-STEM) education fields and in different geographical areas.

Despite its limitations, this study offers important implications for university managers. Indeed, it may help university managers design university curricula in STEM fields that are more conducive to female entrepreneurial entry. To increase the likelihood of recent female STEM graduates becoming entrepreneurs, university managers should include at least one mandatory course in economics and management in STEM MSc degree programs. To stimulate graduate entrepreneurship, university managers may also include multi-program courses in STEM university curricula, but they must be aware that these courses are likely to stimulate the entrepreneurial entry of male graduates only. University managers must also be aware that although internships should be part of STEM university curricula because they help graduates find their first jobs, they probably detract graduates in general and female graduates in particular from the entrepreneurial profession as they push them towards alternative occupations as salaried employees.
Funding Open access funding provided by Libera Università di Bolzano within the CRUI-CARE Agreement.

Data availability Data cannot be disclosed due to privacy concerns.

Code availability Not applicable.

\section{Declarations}

Competing interests The authors declare no competing interests.

Open Access This article is licensed under a Creative Commons Attribution 4.0 International License, which permits use, sharing, adaptation, distribution and reproduction in any medium or format, as long as you give appropriate credit to the original author(s) and the source, provide a link to the Creative Commons licence, and indicate if changes were made. The images or other third party material in this article are included in the article's Creative Commons licence, unless indicated otherwise in a credit line to the material. If material is not included in the article's Creative Commons licence and your intended use is not permitted by statutory regulation or exceeds the permitted use, you will need to obtain permission directly from the copyright holder. To view a copy of this licence, visit http://creativecommons.org/licenses/by/4.0/.

\section{References}

Aldrich, H., Reese, P. R., \& Dubini, P. (1989). Women on verge of a breakthrough: Networking among entrepreneurs in the United States and Italy. Entrepreneurship and Regional Development, 1(4), 339-356.

Alsos, G. A., Isaksen, E. J., \& Ljunggren, E. (2006). New venture financing and subsequent business growth in menand women-led businesses. Entrepreneurship Theory and Practice, 30(5), 667-686.

Amit, R., Glosten, L., \& Muller, E. (1990). Entrepreneurial ability, venture investments, and risk sharing. Management Science, 36(10), 1233-1246.

Arenius, P., \& Minniti, M. (2005). Perceptual variables and nascent entrepreneurship. Small Business Economics, 24(3), 233-247.

Armuña, C., Ramos, S., Juan, J., Feijóo, C., \& Arenal, A. (2020). From stand-up to start-up: Exploring entrepreneurship competences and STEM women's intention. International Entrepreneurship and Management Journal, 16(1), 69-92.

Azam Roomi, M., Harrison, P., \& Beaumont-Kerridge, J. (2009). Women-owned small and medium enterprises in England: Analysis of factors influencing the growth process. Journal of Small Business and Enterprise Development, 16(2), 270-288.

Baron, R. A., Markman, G. D., \& Hirsa, A. (2001). Perceptions of women and men as entrepreneurs: Evidence for 
differential effects of attributional augmenting. Journal of Applied Psychology, 86(5), 923-929.

Becker, G. S. (1964). Human capital. Columbia University Press.

Bengtsson, C., Persson, M., \& Willenhag, P. (2005). Gender and Overconfidence. Economic Letters, 86(2), 199-203.

Berger, A. N., \& Udell, G. F. (1998). The economics of small business finance: The roles of private equity and debt markets in the financial growth cycle. Journal of Banking and Finance, 22(6-8), 613-673.

Bergmann, H., Hundt, C., \& Sternberg, R. (2016). What makes student entrepreneurs? On the relevance (and irrelevance) of the university and the regional context for student startups. Small Business Economics, 47(1), 53-76.

Bittmann, F., \& Zorn, V. S. (2020). When choice excels obligation: About the effects of mandatory and voluntary internships on labour market outcomes for university graduates. Higher Education, 80(1), 75-93.

Brana, S. (2013). Microcredit: An answer to the gender problem in funding? Small Business Economics, 40(1), $87-100$

Brescoll, V. L. (2016). Leading with their hearts? How gender stereotypes of emotion lead to biased evaluations of female leaders. The Leadership Quarterly, 27(2), 415-428.

Breznitz, S. M., \& Zhang, Q. (2020). Determinants of graduates' entrepreneurial activity. Small Business Economics, 55, 1039-1056.

Brindley, C. (2005). Barriers to women achieving their entrepreneurial potential: Women and risk. International Journal of Entrepreneurial Behavior \& Research, 11(2), 144-161.

Brush, C. G. (1992). Research on women business owners: Past trends, a new perspective and future directions. Entrepreneurship Theory and Practice, 17(4), 5-30.

Carroll, G. R., \& Mosakowski, E. (1987). The career dynamics of self-employment. Administrative Science Quarterly, 32(4), 570-589.

Carter, N., Brush, C., Greene, P., Gatewood, E., \& Hart, M. (2003). Women entrepreneurs who break through to equity financing: The influence of human, social and financial capital. Venture Capital, 5(1), 1-28.

Carter, N. M., Williams, M., \& Reynolds, P. D. (1997). Discontinuance among new firms in retail: The influence of initial resources, strategy, and gender. Journal of Business Venturing, 12(2), 125-145.

Carter, S., Shaw, E., Lam, W., \& Wilson, F. (2007). Gender, entrepreneurship, and bank lending: The criteria and processes used by bank loan officers in assessing applications. Entrepreneurship Theory and Practice, 31(3), 427-444.

Chwe, M.S.-Y. (2001). Rational ritual: Culture, coordination, and common knowledge. Princeton University Press.

Clark, H. (1996). Using language. Cambridge University Press.

Coleman, S. (2000). Access to capital and terms of credit: A comparison of men- and women-owned small businesses. Journal of Small Business Management, 38(3), 37-52.

Colombo, M. G., \& Piva, E. (2020). Start-ups launched by recent STEM university graduates: the impact of university education on entrepreneurial entry. Research Policy, 49(6).

Cooper, A. C., Gimeno-Gascon, F. J., \& Woo, C. Y. (1994). Initial human and financial capital as predictors of new venture performance. Journal of Business Venturing, 9(5), 371-395.

Coviello, N. E., \& Cox, M. P. (2006). The resource dynamics of international new venture networks. Journal of International Entrepreneurship, 4(2), 113-132.

Cromie, S., \& Birley, S. (1990). Networking by female business owners in northern Ireland. Journal of Business Venturing, 7(3), 237-251.

De Pater, I. E., Van Vianen, A. E. M., \& Bechtoldt, M. N. (2010). Gender differences in job challenge: A matter of task allocation. Gender, Work and Organization, 17(4), 433-453.

Dilli, S., \& Westerhuis, G. (2018). How institutions and gender differences in education shape entrepreneurial activity: A cross-national perspective. Small Business Economics, 51(2), 371-392.

Dunn, T., \& Holtz-Eakin, D. (2000). Financial capital, human capital, and the transition to self-employment: Evidence from intergenerational links. Journal of Labor Economics, 18(2), 282-305.

Eagly, A. H., \& Karau, S. J. (2002). Role congruity theory of prejudice toward female leaders. Psychological Review, 109(3), 573-598.

Eddleston, K. A., Ladge, J. J., Mitteness, C., \& Balachandra, L. (2016). Do you see what I see? signaling effects of gender and firm characteristics on financing entrepreneurial ventures. Entrepreneurship Theory and Practice, 40(3), 489-514.

Edelman, L. F., Donnelly, R., Manolova, T., \& Brush, C. G. (2018). Gender stereotypes in the angel investment process. International Journal of Gender and Entrepreneurship, 10(2), 134-157.

Estrin, S., \& Mickiewicz, T. (2011). Institutions and female entrepreneurship. Small Business Economics, 37(4), 397-415.

Farr-Wharton, R., \& Brunetto, Y. (2007). Women entrepreneurs, opportunity recognition and government-sponsored business networks - a social capital perspective. Women in Management Review, 22(3), 187-207.

Fay, M., \& Williams, L. (1993). Gender bias and the availability of business loans. Journal of Business Venturing, 8(4), 363-376.

Fielden, S. L., Davidson, M. J., Dawe, A. J., \& Makin, P. J. (2003). Factors inhibiting the economic growth of female owned small businesses in North West England. Journal of Small Business and Enterprise Development, 10(2), 152-166.

Georgellis, Y., \& Wall, H. J. (2005). Gender differences in selfemployment. International Review of Applied Economics, 19(3), 321-342.

Gimenez-Jimenez, D., Edelman, L. F., Dawson, A., \& Calabrò, A. (2020). Women entrepreneurs' progress in the venturing process: the impact of risk aversion and culture. Small Business Economics, 1-21.

Greene, P. (2000). Self-employment as an economic behavior: An analysis of self-employed women's human and social capital. National Journal of Sociology, 12(1), 1-55. 
Greve, A., \& Salaff, J. W. (2003). Social networks and entrepreneurship. Entrepreneurship Theory and Practice, 28(1), 1-22.

Hacker, H. M. (1951). Women as a minority group. Social Forces, 30(1), 60-69.

Hampton, A., Cooper, S., \& McGowan, P. (2009). Female entrepreneurial networks and networking activity in technology-based ventures: An exploratory study. International Small Business Journal, 27(2), 193-214.

Hampton, A., McGowan, P., \& Cooper, S. (2011). Developing quality in female high-technology entrepreneurs' networks. International Journal of Entrepreneurial Behavior \& Research, 17(6), 588-606.

Harrison, R. T., \& Mason, C. M. (2007). Does gender matter? Women business angels and the supply of entrepreneurial finance. Entrepreneurship Theory and Practice, 31(3), 445-472.

Ibarra, H. (1997). Paving an alternative route: Gender differences in managerial networks. Social Psychology Quarterly, 60(1), 91-102.

Jasko, K., Pyrkosz-Pacyna, J., Czarnek, G., Dukała, K., \& Szastok, M. (2020). The STEM graduate: Immediately after graduation, men and women already differ in job outcomes, attributions for success, and desired job characteristics. Journal of Social Issues, 76(3), 512-542.

Jianakoplos, N. A., \& Bernasek, A. (1998). Are women more risk averse? Economic Inquiry, 36(4), 620-630.

Kacperczyk, A. J. (2013). Social influence and entrepreneurship: The effect of university peers on entrepreneurial entry. Organization Science, 24(3), 664-683.

Kanze, D., Huang, L., Conley, M. A., \& Higgins, E. T. (2018). We ask men to win and women not to lose: Closing the gender gap in startup funding. Academy of Management Journal, 61(2), 586-614.

Kaplan, E. (1988). Women entrepreneurs: constructing a framework to examine venture success and business failures. In B. A. Kirchoff, W. A. Long, W. E. McMullan, K. H. Vesper, \& W. E. Wetzel (Eds.), Frontiers of Entrepreneurship Research. Babson College.

Kapucu, N., \& Hu, Q. (2016). Understanding multiplexity of collaborative emergency management networks. The American Review of Public Administration, 46(4), 399-417.

Kelley, D. J., Baumer, B. S., Brush, C., Greene, P. G., Mahdavi, M., Majbouri, M., ... Heavlow, R. (2017). Global Entrepreneurship Monitor. Retrieved from Wellesley, MA:

Kim, P. H., Aldrich, H. E., \& Keister, L. A. (2006). Access (not) denied: The impact of financial, human, and cultural capital on entrepreneurial entry in the United States. Small Business Economics, 27(1), 5-22.

Kirkwood, J. (2009). Is a lack of self-confidence hindering women entrepreneurs? International Journal of Gender and Entrepreneurship, 1(2), 118-133.

Koellinger, P., Minniti, M., \& Schade, C. (2007). "I think I can, I think I can": Overconfidence and entrepreneurial behavior. Journal of Economic Psychology, 28(4), 502-527.

Kuschel, K., Ettl, K., Díaz-García, C., \& Alsos, G. A. (2020). Stemming the gender gap in STEM entrepreneurshipinsights into women's entrepreneurship in science, technology, engineering and mathematics. International Entrepreneurship and Management Journal, 16(1), 1-15.
Langowitz, N., \& Minniti, M. (2007). The entrepreneurial propensity of women. Entrepreneurship Theory and Practice, 31(3), 341-364.

Levesque, M., \& Minniti, M. (2006). The effect of aging on entrepreneurial behavior. Journal of Business Venturing, 21(2), 177-194.

Lin, N. (2001). Social capital: A theory of social structure and action. Cambridge University Press.

Liñán, F., \& Chen, Y. W. (2009). Development and cross-cultural application of a specific instrument to measure entrepreneurial intentions. Entrepreneurship Theory and Practice, 33(3), 593-617.

Malmström, M., Johansson, J., \& Wincent, J. (2017). Gender stereotypes and venture support decisions: How governmental venture capitalists socially construct entrepreneurs' potential. Entrepreneurship Theory and Practice, 41(5), 833-860.

Malmström, M., Voitkane, A., Johansson, J., \& Wincent, J. (2018). When stereotypical gender notions see the light of day, will they burst? Venture capitalists' gender constructions versus venturing performance facts. Journal of Business Venturing Insights, 9, 32-38.

Marlow, S., \& McAdam, M. (2012). Analyzing the influence of gender upon high-technology venturing within the context of business incubation. Entrepreneurship Theory and Practice, 36(4), 655-676.

Marlow, S., \& Patton, D. (2005). All credit to men? Entrepreneurship, finance, and gender. Entrepreneurship Theory and Practice, 29(6), 717-735.

McClelland, E., Swail, J., Bell, J., \& Ibbotson, P. (2005). Following the pathway of female entrepreneurs: A sixcountry investigation. International Journal of Entrepreneurial Behavior \& Research, 11(2), 84-107.

McDonnell, M., \& Morley, C. (2015). Men and women in IT entrepreneurship: Consolidating and deconstructing gender stereotypes. International Journal of Entrepreneurship and Small Business, 24(1), 41-61.

Meyer, V., Tegtmeier, S., \& Pakura, S. (2017). Revisited: How gender role stereotypes affect the image of entrepreneurs among young adults. International Journal of Gender Entrepreneurship, 9(4), 319-337.

Minniti, M., \& Nardone, C. (2007). Being in someone else's shoes: The role of gender in nascent entrepreneurship. Small Business Economics, 28(2), 223-238.

Moore, D. P., \& Buttner, E. H. (1997). Women entrepreneurs: Moving beyond the glass ceiling. Sage Publications.

Northouse, P. G. (2003). Leadership: Theory and practice. Sage.

Nowiński, W., Haddoud, M. Y., Lančarič, D., Egerová, D., \& Czeglédi, C. (2019). The impact of entrepreneurship education, entrepreneurial self-efficacy and gender on entrepreneurial intentions of university students in the Visegrad countries. Studies in Higher Education, 44(2), 361-379.

Oakley, J. G. (2000). Gender-based barriers to senior management positions: Understanding the scarcity of female CEOs. Journal of Business Ethics, 27(4), 321-334.

Ongena, S., \& Popov, A. (2016). Gender bias and credit access. Journal of Money, Credit and Banking, 48(8), 1691-1724. 
Özcan, S., \& Reichstein, T. (2009). Transition to entrepreneurship from the public sector: Predispositional and contextual effects. Management Science, 55(4), 604-618.

Pena, I. (2002). Intellectual capital and business start-up success. Journal of Intellectual Capital, 3(2), 180-190.

Poczter, S., \& Shapsis, M. (2018). Gender disparity in angel financing. Small Business Economics, 51(1), 31-55.

Robb, A. M., \& Robinson, D. T. (2014). The capital structure decisions of new firms. Review of Financial Studies, 27(1), 153-179.

Roberts, E. B. (1991). Entrepreneurs in high technology: lessons from MIT and beyond. Oxford University Press.

Scott, E. L., \& Shu, P. (2017). Gender gap in high-growth ventures: Evidence from a university venture mentoring program. American Economic Review, 107(5), 308-311.

Shapiro, C. A., \& Sax, L. J. (2011). Major selection and persistence for women in STEM. New Directions for Institutional Research, 2011(152), 5-18.

Sørensen, J. B. (2007). Closure and exposure: Mechanisms in the intergenerational transmission of self-employment. Research in Sociology of Organizations, 25(83), 83-124.

Taylor, D. W., Jones, O., \& Boles, K. (2004). Building social capital through action learning: an insight into the entrepreneur. Education + Traning, 46(5), 226-235.

Thébaud, S. (2010). Gender and entrepreneurship as a career choice: Do self-assessments of ability matter? Social Psychology Quarterly, 73(3), 288-304.

Thébaud, S. (2015). Status beliefs and the spirit of capitalism: Accounting for gender biases in entrepreneurship and innovation. Social Forces, 94(1), 61-86.

Thébaud, S., \& Sharkey, A. J. (2016). Unequal hard times: the influence of the great recession on gender bias in entrepreneurial financing. Sociological Science, 3, 1-31.

Tinkler, J. E., Whittington, K. B., Ku, M. C., \& Davies, A. R. (2015). Gender and venture capital decision-making: The effects of technical background and social capital on entrepreneurial evaluations. Social Science Research, 51, $1-16$.

Van der Sluis, J., Van Praag, M., \& Vijverberg, W. (2008). Education and entrepreneurship selection and performance: A review of the empirical literature. Journal of Economic Survey, 22(5), 795-841.
Verheul, I., \& Thurik, R. (2001). Start-up capital:" does gender matter?". Small Business Economics, 16(4), 329-346.

Verheul, I., Uhlaner, L., \& Thurik, R. (2005). Business accomplishments, gender and entrepreneurial self-image. Journal of Business Venturing, 20(4), 483-518.

Wadhwa, V., \& Chideya, F. (2014). Innovating women: The changing face of technology. Diversion Books.

Walter, S. G., Parboteeah, K. P., \& Walter, A. (2013). University departments and self-employment intentions of business students: A cross-level analysis. Entrepreneurship Theory and Practice, 37(2), 175-200.

Walters, J., \& McNeely, C. L. (2010). Recasting Title IX: Addressing gender equity in the science, technology, engineering, and mathematics professoriate. Review of Policy Research, 27(3), 317-332.

Westhead, P., \& Solesvik, M. Z. (2016). Entrepreneurship education and entrepreneurial intention: Do female students benefit? International Small Business Journal, 34(8), 979-1003.

Wilson, F., Kickul, J., \& Marlino, D. (2007). Gender, entrepreneurial self-efficacy, and entrepreneurial career intentions: Implications for entrepreneurship education. Entrepreneurship Theory and Practice, 31(3), 387-406.

Wu, Z., \& Chua, J. H. (2012). Second-order gender effects: the case of U.S. small business borrowing cost. Entrepreneurship Theory and Practice, 36(3), 443-463.

Yang, T., \& Aldrich, H. E. (2014). Who's the boss? Explaining gender inequality in entrepreneurial teams. American Sociological Review, 79(2), 1-25.

Zhang, Z., Zyphur, M. J., Narayanan, J., Arvey, R. D., Chaturvedi, S., Avolio, B. J., ... Larsson, G. (2009). The genetic basis of entrepreneurship: effects of gender and personality. Organizational Behavior and Human Decision Processes, 110(2), 93-107.

Publisher's note Springer Nature remains neutral with regard to jurisdictional claims in published maps and institutional affiliations. 